\title{
Analysis of Present Situation and Research of Reform on Scientific Research Management in Higher Vocational Colleges from the Perspective of Specialization
}

\author{
Li Guannan \\ Taizhou Polytechnic College, Science and Technology Department \\ Taizhou, Jiangsu Province, 225300
}

\begin{abstract}
Scientific research is one of the three major functions of higher education. Higher vocational education, as a part of higher education, naturally assumes the function of scientific research as well. Higher vocational colleges increasingly recognize the role of scientific research in promoting teaching and entire school's development. So, higher vocational colleges are paying more attention to the scientific research work. However, because of the weak foundation of scientific research in higher vocational colleges and prominent problems, the efficiency and quality of scientific research work increase slowly. By analyzing present situation, finding out problems, and proposing countermeasures, the paper analyzes the present situation of scientific research management in higher vocational colleges, summarizes the problems behind, and finally puts forward some countermeasures and reform ideas. This paper explores the reasons for the problems existing in the scientific research management in higher vocational colleges from the perspective of specialization construction, and proposes countermeasures of reform, which are the innovation points of this paper.
\end{abstract}

Keywords-Higher Vocational Colleges; Scientific Research Management; Specialization; System

\section{INTRODUCTION}

In recent years, the development of higher vocational education in China has been booming, the scale of schooling has expanded rapidly, the school system has been continuously improved, and the model of talent training has gradually become clear. Higher vocational education has gradually moved from the extensive development model of expanding education scale to improve the connotation development of education quality. The connotation development has put forward higher requirements for higher vocational education management. Management specialization is the realistic demand for the development of higher vocational education, and also an inevitable choice for the development of higher vocational education. The development of higher vocational education itself has started very late, and the foundation of scientific research is weak, while scientific research will play an important role in the connotation development of China. Analyzing the present situation of scientific research management in higher vocational colleges, finding out the reasons, exploring the thoughts of reform, and putting forward the countermeasures are the important task faced by the scientific research management personnel in higher vocational colleges.

\section{ANALYSIS ON THE PRESENT SITUATION OF SCIENTIFIC} RESEARCH MANAGEMENT IN HIGHER VOCATIONAL COLLEGES

\section{A. Achievements and Progress}

With the continuous development of higher vocational education in our country, higher vocational colleges are paying more attention to the scientific research work and have made greater progress in the aspect of scientific research. It is mainly reflected in the following aspects: Firstly, the scientific research management institutions are established. Scientific research management institutions have been established from scratch. Most of the higher vocational colleges have established specialized scientific research management institutions, such as the Scientific Research Department and the Higher Education Research Institute. Scientific research function has the fulfillment carrier and the scientific research function can be implemented smoothly. Secondly, the scientific research management system has been continuously improved. From top to bottom, schools gradually raised the awareness of the importance of scientific research work. In addition to the strong demand for scientific research development, higher vocational colleges strengthened the reform of the construction of scientific research management system. Schools have formulated the systems related to scientific research achievement awards, the use of scientific research funds and management methods. Some institutions have also established quantitative assessment methods for scientific research work, and scientific research management systems have gradually become standardized and scientific. Thirdly, scientific research abilities and levels have been improved. Due to the historical reasons, the foundation for higher vocational colleges was weak at the beginning of development, and problems such as lack of scientific research atmosphere, weak scientific research consciousness, and low scientific research ability existed everywhere. In recent years, with the rapid development of higher vocational education as a whole, external situation 
driving and internal development needs make higher vocational colleges recognize the importance and urgency of scientific research work. Each institution has established and improved scientific research management mechanisms. The regulation of management and the incentive of the system have led to the continuous enhancement of the scientific research consciousness of the faculty and staff. The enthusiasm for scientific research has been continuously improved, the research atmosphere of the schools has become increasingly strong, the overall scientific research ability and level have been greatly improved, and the quantity and level of scientific research projects and achievements have made a qualitative leap [1].

\section{B. Problems and Insufficiencies}

To sum up, higher vocational colleges have made great progress in scientific research, but there are still problems existing behind the achievements.

(1) The orientation is not clear and there exists deviation. Scientific research orientation is the recognition of the role, purpose and type of scientific research, and determines the direction and effectiveness of scientific research. At present, the scientific research orientation in some higher vocational colleges is still not clear, and there exist deviations in recognition. Firstly, there is still a lack of understanding of the importance and necessity of the scientific research. There is a lack of real understanding of the role of scientific research in the development of the entire higher vocational colleges. It only stays in the attention of form and has not placed scientific research in its rightful place. The input in manpower, material resources, and financial investment is still not enough. Secondly, there is a lack of correct understanding of the purpose of scientific research. They considered that scientific research is the "face engineering" of schools, partially attached importance to the "quantity" of scientific research while ignore the "Quality". Many faculty and staff members have utilitarian scientific research. They simply engage in scientific research for the purpose of obtaining the scientific research funds without considering the role and purpose of scientific research serving personnel training, education teaching, and serving local economic development. Thirdly, they have not started from the training objectives of higher vocational colleges and combined with the actual situation of the schools to determine the focus of the scientific research. According to the different research purposes, and methods as well as the value and significance of the results, the scientific research is generally divided into three types: basic research, applied research and technology development research. The colleges and universities should have a focus on choosing the types of scientific research. However, at present, many higher vocational colleges want to "take everything into their own hands" in scientific research without having a focus. There are all three types of scientific research. They cover a wide range but the strength is not strong enough. They have not placed emphasis on scientific and technological development research and applied research that can exploit their own advantages.

(2)The mechanism is not perfect and grassroots management is absent. Scientific research management is a comprehensive system engineering involving multiple links and needs to be completed in multiple layers. In addition to management at the school level, it also needs grass-root management, mainly including secondary management of the department and project team management, etc. Faculty teachers are the main scientific researches in higher vocational colleges. Academic research and management is related to the overall level of the school's scientific research. The management of this link cannot be ignored. Although scientific research institutions are gradually perfected and the management at the school level has been effectively carried out with the increasing awareness of the importance of scientific research for higher vocational colleges, the lack of grassroots management is relatively serious. Due to the restriction of the mechanism and personnel, most of the higher vocational colleges have not set up the primary scientific research institutions at the branch level, and the management work at this level is completed by other people in their part-time. Thus they couldn't perform the secondary management responsibilities very well, thus causing the occurrence of the management faults, which affects the management efficiency and the carrying out of the scientific research work.

(3)The overall level of specialization is not high. Different from general administrative management work, scientific research management is more professional, technical, and comprehensive. It is not pure transactional management but requires certain professional knowledge and job skills. The development of scientific research in higher vocational colleges starts late and the foundation is weak. Although the importance of scientific research has been improved in recent years, the cognition of management specialization is still insufficient. Scientific research management personnel lack professional knowledge and sufficient professional skills. They lack autonomy in management and the specialization level of management is not high. There still exist administrative problems in the scientific research management for some higher vocational colleges. The management is not scientific or normative and the work efficiency is not high, which indirectly influences the teachers' conduction of the research work and the improvement of the overall scientific research level of the schools. 


\section{THOUGHTS ON THE REFORM OF SCIENTIFIC RESEARCH MANAGEMENT IN HIGHER VOCATIONAL COLLEGES}

The reason why there exist problems and deficiencies in scientific research management for higher vocational colleges

\section{A. Macro: To increase the awareness and importance of scientific research and clearly define orientation}

The higher vocational colleges, from the leaders, managers to front-line teachers, should fully realize that scientific research is not only one of the basic functions of higher vocational colleges, but also the need of the self-development of higher vocational colleges. Scientific research is an important part of the connotation construction of higher vocational colleges, and it shoulders the heavy task of exploring laws, serving decisions, innovating theories, and guiding practice [2]. Scientific research is an indispensable work in higher vocational colleges, which plays an important role in the development of higher vocational education, higher vocational colleges' serving society, promotion of teaching level, discipline construction and professional development. Higher vocational colleges should stand at the height of the scientific outlook on development to improve the importance of scientific research and correctly understand the role of scientific research. At the school level, they must pay attention to scientific research not only in terms of form but also in content, increase the input in scientific research manpower, material resources and financial resources, establish a scientific research policy of guidance and inclination, stimulate the enthusiasm of teachers to carry out scientific research, and form a good atmosphere of promote teaching with scientific research and promoting management with scientific research. At the teacher level, it is necessary to correctly understand the role and purpose of scientific research, enhance the quality of scientific thinking, and make clear that scientific research and teaching are just a routine job for teachers, rather than the short-term effectiveness for winning the job title. Think positively, try to find the subjects in teaching and production, look for projects in work-study combination and schoolenterprise cooperation, and enhance its own teaching and professional standards while realizing the role of scientific research in promoting teaching and serving localities.

While increasing emphasis, we must also clarify scientific research orientation. Higher vocational colleges must scientifically and objectively assess their own existing conditions and accurately and reasonably determine the scientific research orientation. They must not blindly copy the models of other colleges and universities, nor should they set too high to pursuit greatness and completeness. They should adhere to the principle of do things according to their abilities and pay attention to the actual results. On the one hand, they should base on their own college and face the front line of teaching to serve the talent training and education teaching. Proceeding from the practice of education and teaching, aiming at solving the problems, they need to carry out the research on vocational and technical education system, school-running mechanism and personnel training mode reform, vocational and technical education specialty and course system, practice teaching reform, teaching staff training, informatization construction and so on to solve the problems and confusions is that the specialization level is insufficient and the scientific research management cannot meet the needs of scientific research work. The reform of scientific research management should strengthen the specialization construction from different levels and improve the specialization level.

emerged in the teaching practice of vocational and technical education [3]. On the other hand, they should base on local conditions and face the front line of production to serve the local economic development. Encourage the teachers to strengthen exchanges and contacts with enterprises and industries, identify problems from production and solve problems. Set achievements transfer, technology development and product development as the goal, look for projects from the front line, and carry out the scientific research and technical services. At the same time, take an active part in local policy mechanism and development strategy research to provide the best decision-making, strategy, thought and method for local development.

\section{B. Meso: To improve the scientific research management mechanism and strengthen grassroots management}

In view of the lack of management at the grassroots level, the establishment of sound scientific research management mechanisms and the strengthening of grass-roots management are the top priority for the reform of management in higher vocational colleges. Establish a professional three-level management system that consists of the school's scientific research management department, the secondary department management institution and the project team. Different levels of departments have different responsibilities, forming a management chain with multi-sector responsibility and hierarchical management. Each department performs its own duties, conducts specialization management, and forms a good collaborative management mechanism. The school scientific research management department is mainly responsible for the formulation of school scientific research planning, scientific research management related system, the examination and submission of scientific research projects and achievement awards, allocation of scientific research funds, tracking and inspection of scientific research projects, provision of scientific research information service and foreign exchange coordination and other macroscopic work. The secondary colleges or departments are mainly responsible for the deployment and implementation of the research work of the department, the progress inspection of scientific research projects, the management of scientific research funds, the construction of scientific research team, and other relatively specific work. The work of the project team is more specific and detailed, which is mainly responsible for the implementation of the research work of the project, including the specific division of work of the members of the project, the collection and arrangement of materials, the use of instruments, equipment and experimental materials, the specific use and review of funds, and the conversion of the final achievements, etc [4]. The management of secondary colleges or departments is the key link in the chain of scientific research management, which plays the role of reporting to the upper levels and make known to the lower levels and serves as a connecting link between the preceding and the following. To the upper levels, they can discuss the problems of specialty and technology with 
the scientific research management department of the school, and make plans for the scientific research management of the school; to the lower levels, they can directly contact the project team, and transmit the information of the school scientific research management department to the project team in time. Therefore, higher vocational colleges must attach great importance to secondary scientific research management, strengthen the construction of secondary scientific research management, equip with strong management personnel, improve the specialization level of management, and ensure the effectiveness of management. At the same time, they must standardize the management of the project team, strengthen the construction of scientific research team, mobilize and stimulate the enthusiasm of grass-roots scientific research management, and improve the quality and level of the project.

\section{Micro: To strengthen the specialization construction of scientific research management personnel and improve management level}

Management lies in the manager fundamentally and the business level of the manager is the most important factor that influences the management innovation ability. Scientific research management is a highly technical work, which requires a "specialized" team that knows the science, have good management and high quality. Specialization requires the scientific research management personnel to have strong comprehensive quality and ability. The scientific research management personnel of higher vocational colleges must understand and grasp the characteristics and laws of scientific research management in higher vocational colleges; they must have reasonable knowledge structure, have a wide knowledge scope while having strong professional knowledge, and have a certain scientific research strength; they must have strong sense of responsibility and service awareness, pragmatic principles and spirit of seeking truth from facts. In the work, they can exert their own subjective initiative, blaze new trails in a pioneering spirit, have advanced management concepts, strong practical management capabilities and organizational coordination capabilities [5]. The social division of labor and the need for self-development have put forward new and higher requirements for colleges and universities management, and specialization has become the inevitable trend for the development of colleges and universities. The higher vocational colleges must strengthen the specialization construction of scientific research management personnel, establish the access mechanism, training mechanism, examination mechanism, and incentive mechanism for the management personnel, improve the professional accomplishment and service ability of the scientific research management personnel, realize the standardization, specialization and scientification of scientific research management, and promote the healthy and sound development of the scientific research work in higher vocational colleges [6]

\section{CONCLUSION}

The rapid development of vocational and technical education puts forward a new and higher requirement for higher vocational education management, and the specialization of management is an inevitable trend for the development of higher vocational colleges. The development of higher vocational colleges started late, the foundation of scientific research was weak, and there are still many problems in actual management. For example, there exist obscurity and deviation in the position of scientific research, the scientific research management mechanism is not perfect, the lack of grass-roots management is serious, the construction of management specialization is lagging behind, and the professional level of the scientific research management personnel is not high. In order to meet the overall development trend and the needs of its own development, scientific research management in higher vocational colleges must be reformed. The reform should set management specialization as the guidance, improve the specialization level comprehensively from the three levels of macro ideological emphasis and goal orientation, the meso sound mechanism, and the micro professional training of the management personnel, enhance the efficiency and quality of scientific research management, promote the effective carrying out of the scientific research work, enhance the overall scientific research level of higher vocational colleges, and form a good situation where scientific research promotes teaching, and teaching and scientific research advances hand in hand.

\section{ACKNOWLEDGMENT}

Fund Project: The Master and Docter Foundation Project of Taizhou Polytechnic College "Study on the Specialization of Scientific Research and Management in Higher Vocational Colleges Based on Orientation Analysis"(No. TZYBS-15-7), hosted by: Li GuanNan.

Profile of Author: Li Guannan (1981- ), born in Hengshui, Hebei Province, Lecturer of Taizhou Polytechnic College, Master, with Research Direction in Science and Technology Management, Education Management and Industrial Economy.

\section{REFERENCES}

[1] Zhu Qin. Research on Present Situation and Countermeasures of Scientific Research Management in Higher Vocational Colleges [J]. Vocational Education Research, 2012(4). (In Chinese)

[2] Du Shanbao. Scientific Research Difficulties and Countermeasures in Higher Vocational Colleges - - Take Y Vocational and Technical College as an Example [J]. Journal of Yan'an Vocational and Technical Institute, 2013(1). (In Chinese)

[3] Chen Gang \& Qian Zhongping. Selection of Scientific Research Management Path in Higher Vocational Colleges Based on the Perspective of Innovation [J]. Chinese Vocational and Technical Education, 2016(29). (In Chinese)

[4] Hu Dongyan. Present Situation Analysis and Countermeasures of Scientific Research Management in Higher Vocational Colleges [J]. Communication of Vocational Education, 2016 (14). (In Chinese)

[5] Pan Xiaoxiao. Analysis on the Problems and Countermeasures of Scientific Research Management Faced by Higher Vocational Colleges [J]. Journal of Yan'an Vocational and Technical Institute, 2017(2). (In Chinese)

[6] Zhang Guoli \& Tian Li. Problems and Countermeasures of Scientific Research Existing in Higher Vocational Colleges [J]. Education and Vocation, 2013(12). (In Chinese) 